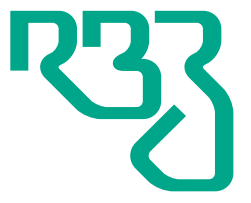

\section{Revista}

Brasileira de

Zootecnia

Brazilian Journal of Animal Science

ISSN 1806-9290

www.rbz.org.br

\title{
The use of guava byproduct in the production of feedlot sheep in Brazil: impacts on the productive and economic performance
}

\author{
Roberto Germano Costa $^{1^{*}}$ (iD, Nelson Vieira da Silva ${ }^{2}$ (iD, Geovergue \\ Rodrigues de Medeiros $^{3}$ (D), Airon Aparecido Silva de $\mathrm{Melo}^{4}$ (iD), Safira \\ Valença Bispo $^{4}$ (iD), Maria Caroline de Almeida Cavalcanti ${ }^{2}$ (iD) \\ ${ }^{1}$ Universidade Federal da Paraíba, Departamento de Ciência Animal, Bananeiras, PB, Brasil. \\ ${ }^{2}$ Instituto Federal de Educação, Ciência e Tecnologia de Alagoas, Departamento de \\ Agroecologia, Murici, AL, Brasil. \\ ${ }^{3}$ Instituto Nacional do Semiárido, Campina Grande, PB, Brasil. \\ ${ }^{4}$ Universidade Federal Rural de Pernambuco, Unidade Acadêmica de Garanhuns, \\ Garanhuns, PE, Brasil.
}

\author{
*Corresponding author: \\ Received: May 2, 2018 \\ Accepted: May 19, 2019 \\ How to cite: Costa, R. G.; Silva, N. V.; Medeiros, \\ G. R.; Melo, A. A. S.; Bispo, S. V. and Cavalcanti, \\ M. C. A. 2019. The use of guava byproduct in the \\ production of feedlot sheep in Brazil: impacts \\ on the productive and economic performance. \\ Revista Brasileira de Zootecnia 48:e20170257. \\ https://doi.org/10.1590/rbz4820170257 \\ Copyright: This is an open access article \\ distributed under the terms of the \\ Creative Commons Attribution License \\ (http://creativecommons.org/licenses/by/4.0/), \\ which permits unrestricted use, distribution, \\ and reproduction in any medium, provided the \\ original work is properly cited.
}

ABSTRACT - This study evaluated the effects of replacing ground corn with dehydrated guava (Psidium guajava L.) byproduct, at concentrations of $0.0,8.2,16.4$, and $24.6 \%$ on the intake and digestibility of nutrients as well as on productive and economic performance of lambs. The study included 40 uncastrated feedlot Santa Inês sheep with an average age of 120 days and an average initial weight of $17.4 \pm 1.27 \mathrm{~kg}$, distributed in individual stalls in a completely randomized design with four treatments and 10 replicates. Santa Inês sheep fed diets containing higher levels (16.4\%) of guava byproduct showed lower weight gain and feed conversion and reached slaughter weight later. Replacing corn with guava byproduct at higher levels increased acid detergent fiber and reduced non-fiber carbohydrate intake and nutrient digestibility. The inclusion of up to $16.4 \%$ of guava byproduct in the diet of feedlot sheep is appropriate for maintaining good performance and economic viability of the system.

Keywords: animal production, feeding, lamb, nutrition

\section{Introduction}

Due to the variation in forage supply, especially in the drier months of the year, the production of sheep meat is impaired. In this case, the feedlot appears as a strategy to intensify production (Medeiros et al., 2009). Such an approach satisfies both the producer and the consumer, since it enables the availability of young animals with better meat quality on the market (Urano et al., 2006). However, in feedlot systems, it is important that the animals receive diets that meet the nutrient requirements, resulting in a viable cost:benefit ratio for the producer (Medeiros et al., 2009). To amortize costs of the feedlot, the use of alternative feedstuff, such as agroindustry byproducts, has been suggested (Vieira et al., 2010; Lima Júnior et al., 2014; Nicory et al., 2015; Sá et al., 2015; Silva et al., 2016).

In Brazil, large amounts of byproducts from guava (Psidium guajava L.) accrue each year. They are composed of peel, seeds, and pulp, which, after dehydration, can potentially be used in diets for ruminants (Pereira et al., 2008). However, the presence of secondary compounds such as tannins can be a limiting factor for the use of these byproducts (Patra and Saxena, 2010). Brazil is the largest producer of red guavas and produces approximately 390,000 tons of guava annually. The byproduct contains significant amounts of unsaturated fatty acids and fiber (Uchôa-Thomaz et al., 2014). The 
protein content ranges from 7.9 to $9.6 \%$, fat content from 10.5 to $16 \%$, and crude fiber content from 53.6 to $67.7 \%$ (Chang et al., 2014).

When investigating and using agroindustrial byproducts as animal feedstuff, knowledge of productive and economic performance characteristics is crucial for evaluating diet efficiency (Alves et al., 2010; Azevedo et al., 2013; Silva et al., 2015; Silva et al., 2016). Some of the factors that influence animal performance include body weight gain, diet digestibility, feed conversion, and feedlot period (Pinheiro et al., 2009; Geron et al., 2015).

In this context, the objective of this study was to evaluate the effects of including increasing levels of dehydrated agroindustrial guava byproduct to replace corn in terms of intake and nutrient digestibility as well as productive and economic performance of Santa Inês sheep in feedlots.

\section{Material and Methods}

The procedures performed in this experiment were approved by the local Ethics Committee for Animal Experimentation under case no. CETEA 2305/14. The experiment was conducted in Bananeiras, PB, Brazil $\left(08^{\circ} 20\right.$ 'S and $36^{\circ} 25^{\prime} \mathrm{W}$, and average elevation of $\left.608 \mathrm{~m}\right)$. Average annual temperature ranges from 22 to $24^{\circ} \mathrm{C}$, with an average annual rainfall of $800 \mathrm{~mm}$.

We used 40 uncastrated feedlot Santa Inês lambs with an average age of 120 days, and their average weight at the beginning of the study was $17.4 \pm 1.27 \mathrm{~kg}$. The adaptation period to the diet and installation was 15 days, and animals were weighed on a weekly basis until they reached slaughter weight. They were initially dewormed via subcutaneous administration of $1 \%$ Ivermectin and subsequently allocated to individual stalls with an area of $1.8 \mathrm{~m}^{2}$, with free access to feed and water, where they received the experimental diets.

The diets (Table 1) consisted of Tifton-85 hay (30\%, Cynodon dactylon), soybean meal (22.0\%), ground corn (41.0\%), urea (0.5\%), mineral supplement (1.5\%), vegetable oil (5.0\%), and guava agroindustrial byproduct at increasing levels of $0,82,164$, and $246 \mathrm{~g} \mathrm{~kg}^{-1} \mathrm{DM}$, replacing ground corn $(0,20,40$, and $60 \%$, respectively; Table 2). The guava byproduct was collected from guava juice industries in the region, dried in the sun for $\sim 24 \mathrm{~h}$, and subsequently stored in nylon bags for later use. The diets were formulated to achieve a weight gain of $250 \mathrm{~g} \mathrm{day}^{-1}$, as recommended by NRC (2007), with a forage:concentrate ratio of 30:70. The experimental diets were offered ad libitum at $7.30 \mathrm{~h}$ and $16.30 \mathrm{~h}$ in the form of a complete diet. The leftovers from the ration were used to calculate voluntary intake and adjust the amount offered, considering $10 \%$ of leftovers.

Ingredients of diet samples were collected before the preparation of the experimental diets. Diet samples, leftovers, and feces were pre-dried, homogenized, and frozen $\left(-15{ }^{\circ} \mathrm{C}\right)$ for subsequent analyses. Pre-drying was performed in an air-circulation oven at $65^{\circ} \mathrm{C}$ for $72 \mathrm{~h}$. Samples were then crushed in a mill with a 1-mm mesh, labeled, and stored in airtight flasks for determination of dry matter (DM), crude protein (CP), ether extract (EE), mineral matter (MM), and organic matter (OM); all methods were performed according to the methodology described by Silva and Queiroz (2002). Measurements of acid detergent fiber (ADF) and neutral detergent fiber (NDF) were performed

Table 1 - Chemical composition of diet ingredients

\begin{tabular}{|c|c|c|c|c|c|c|c|c|}
\hline Ingredient $\left(\mathrm{g} \mathrm{kg}^{-1}\right)$ & DM & $\mathrm{OM}$ & MM & $\mathrm{CP}$ & $\mathrm{EE}$ & $\mathrm{NDF}^{1}$ & $\mathrm{ADF}^{1}$ & $\operatorname{Lignin}^{1}$ \\
\hline Guava byproduct & 903.5 & 974.7 & 25.3 & 94.4 & 107.2 & 753.0 & 581.8 & 197.0 \\
\hline Tifton hay & 807.3 & 926.1 & 73.9 & 79.8 & 17.4 & 786.4 & 390.4 & 55.0 \\
\hline Ground corn & 875.1 & 969.9 & 30.1 & 85.6 & 57.1 & 135.2 & 38.3 & 11.9 \\
\hline Soybean meal & 877.9 & 937.7 & 62.3 & 470.7 & 20.2 & 155.4 & 96.0 & 15.2 \\
\hline Vegetable oil $^{1}$ & 1000.0 & - & - & - & 999.5 & - & - & - \\
\hline Urea $^{1}$ & 1000 & - & - & 2810 & - & - & - & - \\
\hline
\end{tabular}

DM - dry matter; OM - organic matter; MM - mineral matter; CP - crude protein; NDF - neutral detergent fiber; ADF - acid detergent fiber. ${ }^{1}$ Table values of composition of Valadares Filho et al. (2006). 
according to the methodology proposed by Van Soest et al. (1991). Alpha-amylase was used to obtain NDF. To estimate non-fiber carbohydrates (NFC), the equation recommended by Mertens (1997) was used: $\mathrm{NFC}=100-(\% \mathrm{CP}+\% \mathrm{EE}+\% \mathrm{MM}+\% \mathrm{NDF})$. Total digestible nutrients (TDN) were estimated based on the composition table recommended by Valadares Filho et al. (2006). Digestible energy (DE) was calculated as the product between the TDN content, factor 4.409, and the concentration of metabolizable energy (ME), considered as $82 \%$ of DE (Silva and Leão, 1979). To determine the concentration of total tannins (TT), we used the butanol-HCl method, described by Terrill et al. (1992). Tannin concentration was converted into \% of tannin from Mimosa hostilis, based on standard curve regression, according to Guimarães-Beelen et al. (2006).

After 28 days (four periods of seven days) of the experimental period, the digestibility trial was conducted over in, approximately, 105 days in feedlot. During this period, samples of diets, leftovers, and feces were collected, weighed, and stored at $-15^{\circ} \mathrm{C}$ for further analysis. Fecal samples were directly collected from a rectal swab twice daily $(7.30$ and $16.00 \mathrm{~h})$. At the end of the collection period, these samples were also homogenized and pre-dried in a forced-ventilation oven at $65^{\circ} \mathrm{C}$ for $72 \mathrm{~h}$. All diets, leftovers, and fecal samples were ground in a Willey-type mill with a $2.0-\mathrm{mm}$ sieve for subsequent laboratory analysis.

To determine indigestible neutral detergent fiber (NDFi) concentrations in diets, leftovers, and feces, 1.0 gram of each concentrated ingredient and $0.5 \mathrm{~g}$ of leftovers and feces were incubated in the rumen of an adult cow for a period of $240 \mathrm{~h}$ in TNT bags, according to Casali et al. (2008). The remaining material was extracted with acid detergent, and the resulting residue was considered as the NDFi. Fecal dry matter production (FDMP) was determined via the following formula: FDMP = indicator consumption $(\mathrm{kg}) /$ indicator concentration in feces (\%). To calculate the apparent digestibility of nutrients, the equation proposed by Silva and Leão (1979) was used: coefficient of digestibility (CD) $=$ [nutrient intake (kg) - nutrients in feces $(\mathrm{kg}) /$ consumption of nutrients $(\mathrm{kg})] \times 100$.

Table 2 - Chemical composition of experimental diets according to levels of guava agroindustrial byproduct in substitution of corn in the diet

\begin{tabular}{|c|c|c|c|c|}
\hline \multirow{2}{*}{ Item } & \multicolumn{4}{|c|}{ Guava byproduct level (\%) } \\
\hline & 0.0 & 8.2 & 16.4 & 24.6 \\
\hline \multicolumn{5}{|l|}{ Ingredient $\left(\mathrm{g} \mathrm{kg}^{-1}\right)$} \\
\hline Guava agroindustrial waste ${ }^{1}$ & 0.0 & 82.0 & 164.0 & 246.0 \\
\hline Tifton hay & 300.0 & 300.0 & 300.0 & 300.0 \\
\hline Ground corn & 410.0 & 328.0 & 246.0 & 164.0 \\
\hline Soybean meal & 220.0 & 220.0 & 220.0 & 220.0 \\
\hline Urea & 5.0 & 5.0 & 5.0 & 5.0 \\
\hline Mineral supplement ${ }^{2}$ & 15.0 & 15.0 & 15.0 & 15.0 \\
\hline Vegetable oil & 50.0 & 50.0 & 50.0 & 50.0 \\
\hline \multicolumn{5}{|l|}{ Chemical composition } \\
\hline Dry matter (DM; $\mathrm{g} \mathrm{kg}^{-1}$ as fed) & 843.9 & 846.2 & 848.5 & 850.9 \\
\hline Crude protein (CP; $\left.\mathrm{g} \mathrm{kg}^{-1} \mathrm{DM}\right)$ & 176.7 & 177.4 & 178.1 & 178.8 \\
\hline Ethereal extract (EE; $\mathrm{g} \mathrm{kg}^{-1} \mathrm{DM}$ ) & 82.9 & 86.9 & 91.0 & 94.2 \\
\hline Mineral matter (MM; $\left.\mathrm{g} \mathrm{kg}^{-1} \mathrm{DM}\right)$ & 48.1 & 47.6 & 47.3 & 46.9 \\
\hline Organic matter (OM; $\left.\mathrm{g} \mathrm{kg}^{-1} \mathrm{DM}\right)$ & 881.6 & 882.0 & 882.3 & 882.7 \\
\hline Neutral detergent fiber (NDF; $\mathrm{g} \mathrm{kg}^{-1} \mathrm{DM}$ ) & 403.7 & 440.8 & 478.1 & 515.2 \\
\hline Acid detergent fiber (ADF; $\mathrm{g} \mathrm{kg}^{-1} \mathrm{DM}$ ) & 216.2 & 262.5 & 308.7 & 355.1 \\
\hline Non-fiber carbohydrates (NFC; $\mathrm{g} \mathrm{kg}^{-1} \mathrm{DM}$ ) & 288.6 & 247.3 & 205.5 & 164.9 \\
\hline Total tannin (TT; $\left.\mathrm{g} \mathrm{kg}^{-1} \mathrm{DM}\right)$ & 0.00 & 5.00 & 24.0 & 48.0 \\
\hline Total digestible nutrients (TDN; $\mathrm{g} \mathrm{kg}^{-1} \mathrm{DM}$ ) & 791.8 & 750.4 & 708.9 & 667.4 \\
\hline Metabolizable energy (ME; Mcal kg-1 DM) & 2.86 & 2.70 & 2.55 & 2.41 \\
\hline
\end{tabular}

${ }^{1}$ Composition of guava agroindustrial waste (in $\mathrm{g} \mathrm{kg}^{-1}$ ): DM, 903; OM, 974; MM, 25.3; CP, 94.4; NDF, 750; ADF, 683; TC, 773; NFC, 224.

${ }^{2}$ Composition of mineral supplement per kg: P, 70 g; Ca, 140 g; Na, 148 g; S, 12 g; Mg, 1320 mg; F, 700 mg; Zn, 4700 mg; Mn, 3690 mg; Fe, 2200 mg. Co, 140 mg; I, 61 mg; Se, 15 mg; sodium nonensin, 100 mg. 
Animals that reached $32.0 \mathrm{~kg}$ body weight were slaughtered, and at 105 days of confinement, the remainder was slaughtered, regardless of weight. The animals were subjected to fasting of solids and water diet for $18 \mathrm{~h}$ and slaughtered according to the norms in force in the Regulation of Industrial and Sanitary Inspection of Products of Animal Origin (Brasil, 2000). The animals were weighed at the beginning of the experiment and before slaughter to measure the initial (IW) and final (FW) weights, respectively. Slaughter was performed with stunning by cerebral concussion, followed by bleeding through an incision in the jugular vein and carotid artery, later skinned, and eviscerated. The carcasses were taken to a cold chamber with an average temperature of $4{ }^{\circ} \mathrm{C}$, where they remained for $24 \mathrm{~h}$ suspended from hooks by the tendon of the gastrocnemius muscle.

To calculate the diet costs, ingredients were evaluated based on prices of December 2010, considering the average price in the semi-arid region of Pernambuco, Brazil, with an exchange rate of US\$1.00= $\mathrm{R} \$ 1.76$. Thus, the final costs of diets were $\mathrm{R} \$ 0.55,0.53,0.52$, and 0.50 for $0,20,40$, and $60 \%$ inclusion of guava byproduct, respectively. It is important to state that the economic analysis included lamb production and feeding costs. Costs of facilities and labor were considered fixed. The economic analysis considered that all animals were purchased for $\mathrm{R} \$ 4.50 / \mathrm{kg}$ live weight (LW).

Variables used for the economic analysis were recommended by Lana et al. (1999), as follows: average gross income, obtained by multiplying LW by the price per $\mathrm{kg}$ of LW (R\$ $4.50 / \mathrm{kg}$ ); feeding costs, obtained by multiplying the total amount of feed intake by its respective price; and net income, obtained by the difference between the average gross income and feeding cost.

A completely randomized experimental design with four treatments and 10 replicates was used. Data were subjected to analysis of variance and regression analysis. The model used was:

$$
\mathrm{y}_{\mathrm{ij}}=\mu+\mathrm{t}_{\mathrm{i}}+\varepsilon_{\mathrm{ij}}
$$

in which $\mathrm{y}_{\mathrm{ij}}$ is the observed value of each trait, $\mathrm{t}_{\mathrm{i}}$ is the treatment effect, and $\varepsilon_{\mathrm{ij}}$ is the random error with zero mean and variance $\delta^{2}$. The treatment effect was adjusted in a linear regression model.

The criteria used to choose the equations were curved behavior, coefficient of determination $\left(R^{2}\right)$, and significance; for the regression parameters obtained by student's $t$ test, a probability level of $5 \%$ was adopted.

\section{Results}

Dry matter intake (DMI; $1.27 \mathrm{~kg}$ day ${ }^{-1}$ ), DMI\% of LW (5.28\%), and DMI in $\mathrm{g} \mathrm{kg}^{-1} \mathrm{LW}^{0.75}$ (117.0 g) were not affected by the inclusion of guava byproduct ( $\mathrm{P}>0.05$, at all concentrations) (Table 3 ).

The use of levels of the research byproduct negatively influenced $(\mathrm{P}<0.01)$ the TDN, ADF, and NFC intake. The TDN intake decreased linearly $(\mathrm{P}<0.01)$ with each percentage unit of dietary byproduct

Table 3 - Nutrient intake according to levels of guava agroindustrial byproduct in substitution of corn in the diet

\begin{tabular}{|c|c|c|c|c|c|c|}
\hline \multirow{2}{*}{ Item } & \multicolumn{4}{|c|}{ Guava byproduct level (\%) } & \multirow{2}{*}{ SE } & \multirow{2}{*}{ P-value } \\
\hline & 0.0 & 8.2 & 16.4 & 24.6 & & \\
\hline Dry matter intake $\left(\mathrm{kg} \mathrm{day}^{-1}\right)$ & 1.35 & 1.29 & 1.25 & 1.18 & 0.28 & 0.189 \\
\hline Dry matter intake (\%LW) & 5.43 & 5.21 & 5.13 & 5.35 & 1.45 & 0.944 \\
\hline Dry matter intake (g DM kg ${ }^{-1} \mathrm{LW}^{0.75}$ day $^{-1}$ ) & 121.51 & 116.37 & 114.22 & 115.89 & 30.02 & 0.724 \\
\hline Crude protein intake $\left(\mathrm{g} \mathrm{day}^{-1}\right.$ ) & 239.78 & 229.44 & 224.16 & 211.24 & 62.21 & 0.235 \\
\hline Neutral detergent fiber intake $\left(\mathrm{g} \mathrm{day}^{-1}\right)$ & 547.82 & 570.11 & 601.76 & 608.67 & 133.69 & 0.135 \\
\hline Acid detergent fiber intake $\left(\mathrm{g} \mathrm{day}^{-1}\right)$ & 293.38 & 339.50 & 388.55 & 419.52 & 98.12 & $0.001^{1}$ \\
\hline Non-fiber carbohydrates intake $\left(\mathrm{g} \mathrm{day}^{-1}\right.$ ) & 391.63 & 319.85 & 258.65 & 194.81 & 97.80 & $0.001^{2}$ \\
\hline Total digestible nutrients intake $\left(\mathrm{g} \mathrm{day}^{-1}\right)$ & 1010.80 & 917.00 & 841.15 & 692.45 & 134.34 & $0.023^{3}$ \\
\hline
\end{tabular}

LW - live weight; SE - standard error

${ }^{1} \mathrm{Y}=296.12+2.13 \times\left(\mathrm{r}^{2}=0.99\right)$

${ }^{2} \mathrm{Y}=388.98-3.25 \mathrm{x}\left(\mathrm{r}^{2}=0.99\right)$

${ }^{3} \mathrm{Y}=1019.99-5.15 \mathrm{x}\left(\mathrm{r}^{2}=0.97\right)$. 
inclusion; a reduction in intake of the order of $5.15 \mathrm{~g}$ TDN was observed (Table 3). This behavior of TDN intake can be explained by the absence of an effect on DMI and by the TDN content in the experimental diets (Table 1), which is directly related to the lower energy content of the guava byproduct compared with corn.

Acid detergent fiber intake decreased linearly $(\mathrm{P}<0.01)$; about $2.13 \mathrm{~g}$ of ADF were consumed per day for each percentage unit of guava byproduct included in the diet. Importantly, besides the $13.9 \%$ increase in ADF contents (between the lowest and highest substitution levels), there was also a reduction of $15.7 \%$ in TDN levels. The diet significantly influenced NFC intake $(\mathrm{P}<0.01)$; the addition of guava byproduct resulted in a linear reduction of $18.3,33.9$, and $50.2 \%$ at inclusion levels of $8.2,16.4$, and $24.6 \%$, respectively.

Increasing levels of guava byproduct in the diet had a decreasing linear effect $(\mathrm{P}<0.01)$ on digestibility coefficients of DM, OM, CP, EE, NDF, and ADF (Table 4).

An increasing linear relationship $(\mathrm{P}<0.01)$ was observed with NFC digestibility, which may be related to digestion of corn.

Diet had an effect $(\mathrm{P}<0.01)$ on final $\mathrm{LW}$, feedlot days, ADG, carcass weight, carcass dressing, and feed conversion (Table 5). The final weight of lambs decreased linearly as the levels of guava byproduct in the diet increased $(\mathrm{P}<0.01)$, indicating that for each unit of guava byproduct added, the animals lost on average $16 \mathrm{~g}$. This fact may be related to the reduction in TDN levels and the increase in lignin contents. In addition, the influence of dietary tannins (Table 3) increased as the levels of guava byproduct increased. There was a linear decrease $(\mathrm{P}<0.01)$ in ADG with increasing levels of guava byproduct.

While there was no effect of the diet on DMI, lower levels of guava byproduct were more efficient ( $\mathrm{P}<0.01$ ), defined by the lowest feed conversion values of $5.23,5.71$, and $5.62 \mathrm{~kg} \mathrm{DM} \mathrm{kg}^{-1} \mathrm{ADG}$ for $0,8.2$, and $16.4 \%$, respectively.

The intake and cost of diets increased $(\mathrm{P}<0.01)$ as the levels of guava byproduct in the diet increased (Table 6). Mean gross income was not affected by the inclusion of the guava byproduct $(P>0.01)$, reflecting the influence of weight at slaughter on this variable, given that all animals were slaughtered and sold with similar weights and for similar prices. Moreover, net income (gross income/feeding costs) decreased significantly, which corresponds to losses of $R \$ 4.03, R \$ 3.91$, and $R \$ 14.58$ between diets without and those with $8.2,16.4$, and $24.6 \%$ of guava byproduct, respectively.

Table 4 - Apparent digestibility of nutrients according to levels of guava agroindustrial byproduct in substitution of corn in the diet of sheep

\begin{tabular}{|c|c|c|c|c|c|c|}
\hline \multirow{2}{*}{ Apparent digestibility (\%) } & \multicolumn{4}{|c|}{ Guava byproduct level (\%) } & \multirow{2}{*}{ SE } & \multirow{2}{*}{ P-value } \\
\hline & 0.0 & 8.2 & 16.4 & 24.6 & & \\
\hline Dry matter & 83.47 & 68.20 & 67.16 & 61.06 & 9.26 & $<0.001^{1}$ \\
\hline Organic matter & 82.84 & 66.66 & 65.70 & 59.53 & 9.64 & $<0.001^{2}$ \\
\hline Crude protein & 90.82 & 76.91 & 75.82 & 69.57 & 8.63 & $<0.001^{3}$ \\
\hline Ether extract & 90.75 & 82.62 & 83.38 & 80.71 & 4.96 & $<0.001^{4}$ \\
\hline Neutral detergent fiber & 84.52 & 64.24 & 56.14 & 47.67 & 15.07 & $<0.001^{5}$ \\
\hline Acid detergent fiber & 80.22 & 56.09 & 48.72 & 40.41 & 16.87 & $<0.001^{6}$ \\
\hline Non-fiber carbohydrates & 77.52 & 62.44 & 78.21 & 91.58 & 10.95 & $<0.001^{7}$ \\
\hline
\end{tabular}

SE - standard error.

${ }^{1} \mathrm{Y}=83.47-1.44 \mathrm{x}\left(\mathrm{r}^{2}=0.99\right)$.

${ }^{2} \mathrm{Y}=82.84-1.53 \mathrm{x}\left(\mathrm{r}^{2}=0.99\right)$.

${ }^{3} \mathrm{Y}=90.82-1.31 \mathrm{x}\left(\mathrm{r}^{2}=0.99\right)$.

${ }^{4} \mathrm{Y}=88.77-0.14 \times\left(\mathrm{r}^{2}=0.74\right)$

${ }^{5} \mathrm{Y}=83.89-1.03 \mathrm{x}\left(\mathrm{r}^{2}=0.98\right)$.

${ }^{6} \mathrm{Y}=79.34-1.22 \mathrm{x}\left(\mathrm{r}^{2}=0.98\right)$

${ }^{7} \mathrm{Y}=77.52+2.07 \mathrm{x}\left(\mathrm{r}^{2}=0.99\right)$. 
Table 5 - Performance of Santa Inês lambs according to increasing levels of guava agroindustrial byproduct in the diet

\begin{tabular}{|c|c|c|c|c|c|c|}
\hline \multirow{2}{*}{ Characteristic } & \multicolumn{4}{|c|}{ Guava byproduct level (\%) } & \multirow{2}{*}{ SE } & \multirow{2}{*}{ P-value } \\
\hline & 0.0 & 8.2 & 16.4 & 24.6 & & \\
\hline Initial weight (kg) & 17.45 & 17.34 & 17.11 & 17.74 & 1.56 & 0.643 \\
\hline Final live weight (kg) & 32.47 & 32.13 & 31.94 & 25.30 & 1.29 & $<0.001^{1}$ \\
\hline Average daily gain (kg) & 0.26 & 0.22 & 0.22 & 0.12 & 0.05 & $<0.001^{2}$ \\
\hline Carcass weight (kg) & 15.09 & 13.95 & 13.37 & 11.91 & 1.35 & $<0.001^{3}$ \\
\hline Carcass dressing (\%) & 48.93 & 46.31 & 44.85 & 42.08 & 3.34 & $<0.001^{4}$ \\
\hline FC (kg DM/kg ADG) & 5.23 & 5.71 & 5.62 & 7.91 & 1.56 & $<0.001^{5}$ \\
\hline
\end{tabular}

FC - feed conversion; ADG - average daily gain; SE - standard error.

${ }^{1} \mathrm{Y}=32.39-0.016 \mathrm{x}\left(\mathrm{r}^{2}=0.95\right)$

${ }^{2} \mathrm{Y}=0.26-0.004 \times\left(\mathrm{r}^{2}=0.99\right)$.

${ }^{3} \mathrm{Y}=15.10-0.050 \times\left(\mathrm{r}^{2}=0.97\right)$

${ }^{4} \mathrm{Y}=48.84-0.109 \mathrm{x}\left(\mathrm{r}^{2}=0.98\right)$

${ }^{5} \mathrm{Y}=5.37+0.028 \mathrm{x}\left(\mathrm{r}^{2}=0.90\right)$

Table 6 - Mean and regression equation of variables used in the economic analysis of Santa Inês sheep fed different levels of guava byproduct

\begin{tabular}{|c|c|c|c|c|c|c|}
\hline \multirow{2}{*}{ Characteristic } & \multicolumn{4}{|c|}{ Guava byproduct level (\%) } & \multirow{2}{*}{ SE } & \multirow{2}{*}{ P-value } \\
\hline & 0.0 & 8.2 & 16.4 & 24.6 & & \\
\hline Intake (kg) & 82.50 & 93.31 & 90.14 & 113.53 & 17.57 & $<0.001^{2}$ \\
\hline Cost of diets $(\mathrm{R} \$)^{1}$ & 46.05 & 50.32 & 46.91 & 56.82 & 8.21 & $0.004^{3}$ \\
\hline Mean gross income (R\$) & 66.57 & 66.81 & 63.51 & 62.76 & 11.54 & 0.300 \\
\hline Net income (R\$) & 20.51 & 16.48 & 16.60 & 5.93 & 16.03 & $0.006^{4}$ \\
\hline
\end{tabular}

SE - standard error

${ }^{1} \mathrm{US} \$ 1.00=\mathrm{R} \$ 1.76$

${ }^{2} \mathrm{Y}=82.50+1.56 \times\left(\mathrm{r}^{2}=0.99\right)$.

${ }^{3} \mathrm{Y}=46.05+0.75 \mathrm{x}\left(\mathrm{r}^{2}=0.99\right)$

${ }^{4} \mathrm{Y}=21.42-0.21 \mathrm{x}\left(\mathrm{r}^{2}=0.81\right)$

\section{Discussion}

In this experimental trial, DMI was determined in the confinement period, which differed across diets, thus enabling animals fed higher concentrations of guava byproduct to consume more feed to reach the final live weight. The results obtained were within the standards recommended by the NRC (2007) for sheep in this category, ranging from 1.0 to $1.3 \mathrm{~kg} \mathrm{day}^{-1}$, assuming an ADG between 220 and $260 \mathrm{~g} \mathrm{day}^{-1}$, except for animals fed $60 \%$ of guava byproduct, for which the ADG was $120 \mathrm{~g}$. Average DMI based on LW percentage was slightly higher than values recommended by the NRC (2007), which are 4.3 at $5.0 \%$ of LW for lambs weighing from 20 to $30 \mathrm{~kg}$. However, using guava byproduct in the diet for sheep, Lousada Junior et al. (2005) reported an average DMI of 4.4\% of LW.

The DMI in relation to metabolic weight $\left(117.00 \mathrm{~g} \mathrm{~kg}^{-1} \mathrm{LW}^{0.75} /\right.$ day) at all inclusion levels was above the values recommended by the NRC (2007), which is $100 \mathrm{~g} \mathrm{~kg}^{-1} \mathrm{LW}^{0.75} /$ day, and corroborates the results obtained by Lousada Junior et al. (2005), who observed an intake of $106.8 \mathrm{~g} \mathrm{~kg}^{-1} \mathrm{LW}^{0.75} /$ day in total DM, indicating a good palatability of this byproduct.

All diets (except for the $60 \%$ inclusion) met the requirements of $0.84 \mathrm{~kg} /$ day for sheep, recommended by the NRC (2007). The inclusion of $60 \%$ guava byproduct led to a decrease in animal performance (Table 4). According to the NRC (2007), the nutritional requirements during this phase are around $14-16 \%$ CP and 70-78\% TDN of total DM, whilst consuming around 4.5-5.0\% of LW in the DM providing at least $60 \%$ of concentrate, based on corn and oil bran in diets. This may have stimulated the intake of dietary fiber by the animals to compensate for dietary deficiency (Van Soest, 1994).

This reduction is related to lower NFC dietary levels as well as the increase in NDF and ADF contents due to the addition of guava byproduct. Therefore, diets with lower levels of guava byproduct and, 
consequently, higher NFC concentrations showed higher solubility, a higher fermentation rate, and a shorter residence time in the rumen, according to Regadas Filho et al. (2011).

This may be a consequence of the high percentage of seeds in the guava byproduct, which has a high specific density, thus increasing digestion time and reducing digestibility (Azevedo et al., 2011). The apparent digestibility coefficients of DM, OM, CP, EE, NDF, and ADF decreased by 1.44, 1.53, 1.31, 0.14, 1.03 , and $1.22 \%$ per unit of guava inclusion, respectively. The decrease in digestibility coefficients of DM and OM may have been due to the greater concentration of NFC present in corn (65.4\%) compared with the guava byproduct (12.7\%). Regarding the biological value of $\mathrm{CP}$, which is different between guava byproduct and corn, it promotes a reduction in digestible protein absorption, as reported by Silva et al. (2011).

Organic matter intake was $1,196.3,1,140.7,1,110.5$, and $1,042.8$ g day $^{-1}$. The apparent digestibility coefficients of $\mathrm{OM}$ were $82.84,66.66,65.70$, and 59.53 for the different levels of dietary guava byproduct. Therefore, it could be inferred that the sheep consumed 991.0, 760.4, 729.6, and $620.8 \mathrm{~g}$ of digestible organic matter, according to the levels of guava byproduct, i.e., guava byproduct promoted a reduction in the availability of this nutrient. A high correlation between OM digestibility and energy content of the diets was reported by AFRC (1993). However, in our study, the energy content decreased with increasing levels of guava byproduct to replace corn.

Regarding digestibility of DM, OM, and NDF, Azevedo et al. (2011) used levels of 10 and $30 \%$ of guava byproduct in diets for heifers and observed digestibility coefficients of 57.2 and 50.5\% for DM, 60.2 and $52.7 \%$ for $\mathrm{OM}$, and 58.2 and $48.7 \%$ for NDF, which were lower than those observed in this study. However, higher levels of guava byproduct in the diet causes a reduction in the digestibility of these constituents, supporting the results of the present study.

The reduction in NDF and ADF digestibility was 1.03 and $1.22 \%$ per unit of guava byproduct included in the diet. The NDF digestibility may have been influenced by the contents of the cell wall, in addition to its own structure and organization. The high lignin content $22.1 \%)$ of the guava byproduct, as reported by Azevedo et al. (2011), may have contributed to the lower digestibility of ADF and nutrients. In this context, Costa et al. (2010) reported that lignin participates in ADF composition and reduces nutrient digestibility and availability of CP. Another hypothesis is related to the presence of tannins, which form complexes with carbohydrates and minerals (Guimarães-Beelen et al., 2006). Importantly, the intake of tannins by ruminants has also been linked to positive effects on nutrition, at average concentrations of 3-4\% of DM. Factors include protection of dietary protein against excessive rumen degradation, reduced ammonia waste, increased absorption of amino acids, tympanite prevention, and, more recently, reduced rumen methane production (Animut et al., 2008; Patra and Saxena, 2010). The present study also found tanning levels in the DM above $4 \%$ with the inclusion of $24.6 \%$ guava byproduct.

According to Hoover (1986), there is a superposition of aminolytic bacteria in relation to those which digest fibers in the competition for the same substrate or for fiber-degrading enzymes, which may be inhibited by NFC or byproducts of its digestion.

The reduction in the TDN concentration in experimental diets as well as the increased indigestibility of nutrients were considered major factors for the slower weight gain. The presence of anti-nutritional factors, such as tannins and lignin, could lead to a strategic behavior in animals, both at a cellular and behavioral levels, to prevent intoxication or mitigate adverse effects (Lima Júnior et al., 2010). This may have influenced the total weight gain of animals in the present study, since guava byproduct contains these compounds.

Weight gain ranged from 260 to $120 \mathrm{~g} \mathrm{day}^{-1}$, suggesting that higher levels of guava lead to lower ADG. The ADG of $260 \mathrm{~g}$, observed in animals fed diet without guava byproduct, was higher than the $250 \mathrm{~g}$ recommended by the NRC (2007) (for lambs with $20 \mathrm{~kg}$ moderate potential for weight gain, receiving diets with energy and protein levels of $81.8 \%$ of TDN and $16.8 \%$ of CP, respectively). In contrast, ADG observed in animals fed $24.6 \%$ guava byproduct $\left(120 \mathrm{~g} \mathrm{day}^{-1}\right)$ were well below the recommended values. 
This fact can be explained by the reduction in the energy fraction of diets (TDN) and by the increase in the fibrous constituents NDF and ADF. Alternatively, this could be explained by the competition between degradation and passage rates (Van Soest, 1994) and the low digestibility of guava byproduct (Azevedo et al., 2011), which directly reflects the amount of feed that passes through the rumen.

Levels of guava byproduct increased the confinement time of animals. Due to the decrease of levels $(\mathrm{P}<0.01)$ in the final weight, mean daily gain, carcass weight and yield, and feed efficiency of animals. Shorter confinement periods reduce age at slaughter and production costs and improve carcass quality and quantity (Medeiros et al., 2009). Guava byproduct levels of 8.2 and $16.4 \%$ could increase confinement by 9.1 days (relative to the control diet), which is relevant for this feedlot sheep breeding system. Comparing the data with previous studies from the literature, it is obvious that animals showed a satisfactory confinement period for the inclusion of up to $16.4 \%$ guava byproduct.

However, the inclusion of $24.6 \%$ guava byproduct showed the lowest feed conversion rate, with an average of $7.91 \mathrm{~kg} \mathrm{DM} \mathrm{kg}^{-1} \mathrm{ADG}$. Considering that animal performance can be expressed in terms of feed intake and use, the inclusion of high level of guava byproduct (60\%) clearly reflects the low availability and digestibility of nutrients (Medeiros et al., 2009).

The fact that increasing the level of guava byproduct reduces total cost of diets $(\mathrm{R} \$ 0.55,0.53,0.52$, and 0.50 for $0.0,8.2,16.4$, and $24.6 \%$ of guava byproduct, respectively) shows some economic viability in relation to the results obtained. Animals fed $24.6 \%$ guava byproduct consumed $31.03 \mathrm{~kg}$ more feed, which corresponds to an increase of $37.56 \%$ relative to control animals (without guava byproduct). This could be expected, since animals fed high amounts of guava byproduct (24.6\%) stayed in confinement for 46.20 days longer before reaching slaughter weight (29.79 kg). Medeiros et al. (2009) reported that the use of concentrate in the diet raises weights and yields of cold carcass, but the increase in concentrate levels does not increase the weights and yields of cuts of the carcass of Morada Nova sheep.

\section{Conclusions}

The substitution of corn by guava byproduct promotes a reduction in the intake of total digestible nutrients (energy), average daily gain, final weight, carcass weight and yield, and feed efficiency of animals. The inclusion of up to $16.4 \%$ of guava byproduct in the diet of feedlot sheep is appropriate for maintaining good performance and economic viability of the system.

\section{Conflict of Interest}

The authors declare no conflict of interest.

\section{Author Contributions}

Conceptualization: R.G. Costa, N.V. Silva and S.V. Bispo. Data curation: N.V. Silva and A.A.S. Melo. Formal analysis: N.V. Silva, G.R. Medeiros and A.A.S. Melo. Funding acquisition: S.V. Bispo. Investigation: N.V. Silva, G.R. Medeiros and M.C.A. Cavalcanti. Methodology: N.V. Silva, G.R. Medeiros, S.V. Bispo and M.C.A. Cavalcanti. Project administration: N.V. Silva. Writing-original draft: R.G. Costa and N.V. Silva. Writingreview \& editing: R.G. Costa and N.V. Silva.

\section{Acknowledgments}

The authors thank the Conselho Nacional de Desenvolvimento Científico e Tecnológico (CNPq), for financial support of this project. We also thank the personnel from the Universidade Federal da Paraíba (UFPB), Instituto Federal de Educação, Ciência e Tecnologia de Pernambuco (IFPE) and the Universidade Federal de Alagoas (UFAL): P. M. G. Beelen, F. Chagas, and G. V. Costa. 


\section{References}

AFRC - Agricultural and Food Research Council. 1993. Energy and protein requirements of ruminants. CAB International, Wallingford, UK.

Alves, E. M.; Pedreira, M. S.; Oliveira, C. A. S.; Aguiar, L. V.; Pereira, M. L. A. and Almeida, P. J. P. 2010. Comportamento ingestivo de ovinos alimentados com farelo da vagem de algaroba associado a níveis de ureia. Acta Scientarium. Animal Sciences 32:439-445.

Animut, G.; Puchala, R.; Goetsch, A. L.; Patra, A. K.; Sahlu, T.; Varel, V. H. and Wells, J. 2008. Methane emission by goats consuming different sources of condensed tannins. Animal Feed Science and Technology 144:228-241. https://doi. org/10.1016/j.anifeedsci.2007.10.015

Azevedo, J. A. G.; Valadares Filho, S. C.; Pina, D. S.; Detmann, E.; Valadares, R. F. D.; Pereira, L. G. R.; Souza, N. K. P. and Silva, L. F. C. 2011. Consumo, digestibilidade total, produção de proteína microbiana e balanço de nitrogênio em dietas com subprodutos de frutas para ruminantes. Revista Brasileira de Zootecnia 40:1052-1060. https://doi.org/10.1590/S151635982011000500017

Azevedo, R. A.; Rufino, L. M. A.; Santos, A. C. R.; Ribeiro Júnior, C. S.; Rodriguez, N. M. and Geraseev, L. C. 2013. Comportamento ingestivo de cordeiros alimentados com torta de macaúba. Arquivo Brasileiro de Medicina Veterinária e Zootecnia 65:490-496. https://doi.org/10.1590/S0102-09352013000200027

Brasil. 2000. Instrução Normativa No. 3, de 17 janeiro 2000. Aprova o regulamento técnico de métodos de insensibilização para o abate humanitário de animais de açougue.

Casali, A. O.; Detmann, E.; Valadares Filho, S. C.; Pereira, J. C.; Henriques, L. T.; Freitas, S. G. and Paulino, M. F. 2008. Influência do tempo de incubação e do tamanho de partículas sobre os teores de compostos indigestíveis em alimentos e fezes bovinas obtidos por procedimentos in situ. Revista Brasileira de Zootecnia 37:335-342. https://doi.org/10.1590/ S1516-35982008000200021

Chang, Y. P.; Tan, M. P.; Lok, W. L.; Pakianathan, S. and Supramaniam, Y. 2014. Making use of guava seed (Psidium guajava L): The effects of pre-treatments on its chemical composition. Plant Foods for Human Nutrition 69:43-49. https://doi.org/10.1007/s11130-013-0396-3

Costa, D. A.; Ferreira, G. D. G.; Araújo, C. V.; Colodo, J. C. N.; Moreira, G. R. and Figueiredo, M. R. P. 2010. Intake and digestibility of diets with levels of palm kernel cake in sheep. Revista Brasileira de Saúde e Produção Animal 11:783-792.

Geron, L. J. V.; Garcia, J.; Costa, F. G.; Aguiar, S. C.; Oliveira, E. B.; Silva, M. I. L.; Cabral, L. S.; Pierangeli, M. A. P.; Zeoula, L. M. and Mexia, A. A. 2015. Ruminal parameters and nitrogen balance in sheep fed diets containing residue from the extraction of tamarindo pulp. Semina: Ciências Agrárias 36:3411-3420.

Guimarães-Beelen, P. M.; Berchielli, T. T.; Beelen, R. and Medeiros, A. N. 2006. Influence of condensed tannins from Brazilian semi-arid legumes on ruminal degradability, microbial colonization and ruminal enzymatic activity in Saanen goats. Small Ruminant Research 61:35-44. https://doi.org/10.1016/j.smallrumres.2005.01.007

Hoover, W. H. 1986. Chemical factors involved in ruminal fiber digestion. Journal of Dairy Science 69:2755-2766. https://doi.org/10.3168/jds.S0022-0302(86)80724-X

Lana, G. R. Q.; Rostagno, H. S.; Donzele, J. L. and Lana, A. M. Q. 1999. Efeito de programas de restrição alimentar sobre o desempenho produtivo e econômico e a deposição de gordura na carcaça de frangos de corte. Revista Brasileira de Zootecnia 28:1302-1309. https://doi.org/10.1590/S1516-35981999000600018

Lima Júnior, D. M.; Monteiro, P. B. S.; Rangel, A. H. N.; Maciel, M. V.; Oliveira, S. E. O. and Freire, D. A. 2010. Antinutritional factors for ruminants. Acta Veterinaria Brasilica 3:132-143.

Lima Júnior, D. M.; Carvalho, F. F. R.; Clementino, R. H.; Batista, A. M. V.; Maciel, M. V.; Ferreira, J. C. S. and Pereira Neto, J. D. 2014. Performance of sheep fed on annatto byproduct. Italian Journal of Animal Science 13:3147. https://doi. org/10.4081/ijas.2014.3147

Lousada Junior, J. E.; Neiva, J. N. M.; Rodriguez, N. M.; Pimentel, J. C. M. and Lôbo, R. N. B. 2005. Consumo e digestibilidade de subprodutos do processamento de frutas em ovinos. Revista Brasileira de Zootecnia 34:659-669. https://doi org/10.1590/S1516-35982005000200036

Medeiros, G. R.; Carvalho, F. F. R.; Batista, A. M. V.; Dutra Junior, W. M.; Santos, G. R. A. and Andrade, D. K. B. 2009. Efeito dos níveis de concentrado sobre as características de carcaça de ovinos Morada Nova em confinamento. Revista Brasileira de Zootecnia 38:718-727. https://doi.org/10.1590/S1516-35982009000400019

Mertens, D. R. 1997. Creating a system for meeting the fiber requirements of dairy cows. Journal of Dairy Science 80:1463-1481. https://doi.org/10.3168/jds.S0022-0302(97)76075-2

Nicory, J. M. C.; Carvalho, G. G. P.; Ribeiro, O. L.; Silva, R. R.; Tosto, M. S. L.; Costa-Lopes, L. S.; Souza, F. N. C. and Nascimento, C. O. 2015. Ingestive behavior of lambs fed diets containing castor seed meal. Tropical Animal Health and Production 47:939-944. https://doi.org/10.1007/s11250-015-0812-9

NRC - National Research Council. 2007. Nutrient requeriments of small ruminants: Sheep, goats, cervids, and new world camelids. National Academic Press, Washington, DC.

R. Bras. Zootec., 48:e20170257, 2019 
Patra, A. K. and Saxena, J. 2010. A new perspective on the use of plant secondary metabolites to inhibit methanogenesis in the rumen. Phytochemistry 71:1198-1222. https://doi.org/10.1016/j.phytochem.2010.05.010

Pereira, L. G. R.; Barreiros, D. C.; Oliveira, L. S.; Ferreira, A. L.; Mauricio, R. M.; Azevedo, J. A. G.; Figueiredo, M. P.; Sousa, L. F. and Cruz, P. G. 2008. Chemical composition and ruminal fermentation kinetics of fruit by-products in south Bahia - Brazil. Livestock Research for Rural Development 20:1-13.

Pinheiro, R. S. B.; Silva Sobrinho, A. S.; Siqueira, G. R. and Andrade, E. N. 2009. Ammonization in the production residue of fodder seeds in the performance and biometry of lambs. Ciência Animal Brasileira 10:711-720.

Regadas Filho, J. G. L.; Pereira, E. S.; Villarroel, A. B. S.; Pimentel, P. G.; Medeiros, A. N.; Fontenele, R. M. and Maia, I. S. G. 2011. Composição corporal e exigências líquidas proteicas de ovinos Santa Inês em crescimento. Revista Brasileira de Zootecnia 40:1339-1346. https://doi.org/10.1590/S1516-35982011000600024

Sá, H. C. M.; Borges, I.; Macedo Junior, G. L.; Neiva, J. N. M.; Sousa, J. T. L. and Paula, S. M. 2015. Intake and ingestive behavior of crossbred lambs fed with babaçu cake (Orbignya spp). Bioscience Journal 31:227-233. https://doi.org/10.14393/BJv31n1a2015-18221

Silva, J. F. C. and Leão, M. I. 1979. Fundamentos de nutrição dos ruminantes. Livroceres, Piracicaba.

Silva, D. J. and Queiroz, A. C. 2002. Análise de alimentos: métodos químicos e biológicos. UFV, Viçosa, MG.

Silva, L. M.; Oliveira, C. H. A.; Rodrigues, F. V.; Rodrigues, M. R. C.; Beserra, F. J.; Silva, A. M.; Lemos, J. C.; Fernandes, A. A. 0. and Rondina, D. 2011. Performance in vivo and carcass characteristics of lambs fed with cashew apple bagasse. Archivos de Zootecnia 60:777-786. https://doi.org/10.4321/S0004-05922011000300065

Silva, D. L. S.; Braga, A. P.; Pontes, F. S. T.; Lima Júnior, D. M. L.; Costa, P. W. P.; Chaves, V. V.; Amâncio, A. V. F. and Braga, Z. C. A. C. 2015. Economic viability and morphometry body and carcass characteristics on sheep fed sunflower cake. Acta Veterinaria Brasilica 9:306-315.

Silva, T. M.; Oliveira, R. L.; Nascimento Júnior, N. G.; Pellegrini, C. B.; Trajano, J. S.; Rocha, T. C.; Bezerra, L. R. and Borja, M. S. 2016. Ingestive behavior and physiological parameters of goat fed diets containing peanut cake from biodiesel. Tropical Animal Health Production 48:59-66. https://doi.org/10.1007/s11250-015-0920-6

Terrill, T. H.; Rowan, A. M.; Douglas, G. B. and Barry, T. N. 1992. Determination of extractable and bound condensed tannin concentration in forage plants, protein concentrate meals and cereal grains. Journal of the Science of Food and Agriculture 58:321-329. https://doi.org/10.1002/jsfa.2740580306

Uchôa-Thomaz, A. M. A.; Sousa, E. C.; Carioca, J. O. B.; Morais, S. M.; Lima, A.; Martins, C. G.; Alexandrino, C. D.; Ferreira, P. A. T.; Rodrigues, A. L. M.; Rodrigues, S. P.; Thomaz, J. C. A.; Silva, J. N and Rodrigues, L. L. 2014. Chemical composition, fatty acid profile and bioactive compounds of guava seeds (Psidium guajava L.). Food Science and Technology 34:485-492. https://doi.org/10.1590/1678-457x.6339

Urano, F. S.; Pires, A. V.; Susin, I.; Mendes, C. Q.; Rodrigues, G. H.; Araujo, R. C. and Mattos, W. R. S. 2006. Desempenho e características da carcaça de cordeiros confinados alimentados com grãos de soja. Pesquisa Agropecuária Brasileira 41:1525-1530. https://doi.org/10.1590/S0100-204X2006001000010

Valadares Filho, S. C.; Magalhães, K. A.; Rocha Júnior, V. R. R. and Capelle, E. R. 2006. Tabelas brasileiras de composição de alimentos para bovinos. Suprema Gráfica Ltda, UFV, Viçosa, MG.

Van Soest, P. J. 1994. Nutritional ecology of the ruminant. Cornell University Press, Washington.

Van Soest, P. J.; Robertson, J. B. and Lewis, B. A. 1991. Methods for dietary fiber, neutral detergent fiber, and nonstarch polysaccharides in relation to animal nutrition. Journal of Dairy Science 74:3583-3597. https://doi.org/10.3168/jds. S0022-0302(91)78551-2

Vieira, M. M. M.; Cândido, M. J. D.; Bomfim, M. A. D.; Severino, L. S.; Zapata, J. F. F.; Beserra, L. T.; Meneses, A. J. G. and Fernandes, J. P. B. 2010. Carcass and non carcass components characteristics of lambs fed with diets containing castor mea. Revista Brasileira de Saúde e Produção Animal 11:140-149. 